\title{
Identifying and Prioritizing the Contributory Factors to the Early Internationalization of International New Ventures in Halal Food Industry
}

\author{
Mehran Rezvani ${ }^{1}$, Ali Davari ${ }^{1}$, Nazanin Parvaneh $^{1}$ \\ ${ }^{1}$ Faculty of Entrepreneurship, University of Tehran, Tehran, Iran \\ Correspondence: Nazanin Parvaneh, Faculty of Entrepreneurship, University of Tehran, Farshi \\ Moghaddam (16th) St. North Kargar Ave. Tehran, Iran.
}

Received: March 20, 2017

Accepted: April 25, $2017 \quad$ Online Published: May 22, 2017

doi:10.5539/ibr.v10n6p189

URL: https://doi.org/10.5539/ibr.v10n6p189

\begin{abstract}
This study seeks to identify and prioritize the determining factors in the early internationalization of international new ventures in Halal food industry. In terms of nature and objective, this is an applied research employing quantitative methods. The process consists of two steps. First, the most important factors in the early internationalization of new ventures were identified through an inquiry into previous literature. Then, a questionnaire was devised and distributed among 80 managers and experts working in new Halal food ventures. Subsequently, the collected data were analyzed by PLS and SPSS software. Results indicate that factors such as the managerial characteristics, the company features, the network, the industry features, technology, company resources, country features, advertisement and the knowledge as well as Halal brands (form the participants' perspective) have respectively contributed to the early internationalization of international new ventures in Halal food industry in Iran.
\end{abstract}

Keywords: contributory factor, early internationalization, Halal food industry, international new venture, prioritization

\section{Introduction}

Time was when international markets were monopolized by competing large corporations while the small and new ventures were operating on a mere local or regional scale. But in recent decades, the business world has undergone significant changes due to internationalization and globalization of commercial activities. For instance, small and new ventures can now enjoy access to international clients, suppliers and partners all over the world and agencies face a new competitive environment (Johnson and Sandberg, 2008).

Considering the highly competitive current circumstances, many new small and medium ventures focus on the development of international commercial activities as an important growth strategy. Thus, unless they can prove successful in foreign markets, these ventures cannot survive in small and saturated markets (Rezvani and Hajifathi, 2013). It must be noted that ample evidence point toward the increasing role of international new ventures in world economy (Hessels, 2008), innovation and creation of employment opportunities (De clercq et al., 2008). Since joining the World Trade Organization, creating employment, etc. are among the main challenges our country must deal with, the internationalization of new enterprises can be of significant economic, social and even political significance. In addition, despite numerous empirical studies on the identification of contributing factors to the internationalization of ventures, especially in developing countries, sufficient knowledge about the internationalization of small and new firms is still lacking (Hohenthal et al., 2003). Compensating this deficiency has been one of the principle motives behind selecting this research topic. Accordingly, identifying the contributing factors to the early internationalization of new ventures is the first step to help other ventures become international.

This study concentrates on Halal food industry. Halal is a global standard, a universal criterion for food hygiene and a stimulus towards the development of food trading between Muslim and non-Muslim countries. Halal food industry refers to a method of production, supply and service which is in accordance with Islamic rules and, therefore, avoids procedures and products that are deemed haram in Islam. Nowadays, in addition to the 57 Islamic countries, the citizens from other counties have also showed interest in consuming Halal food. Moreover, with the 
30 percent increase in the Muslim population of the world, which is due by 2025, Halal production will be unprecedentedly brought into attention. It is said that Halal food will comprise 20 percent of the total international food trade in the future (Yang et al., 2016).

The most prominent prospect for the Iranian Halal food industry is to surpass other countries of the region by achieving first place in Halal food trading by 2025 and to earn a position among the first five member states of the Organization of Islamic Cooperation. Furthermore, Vision 2025 also envisions an annual export share up to 10 percent of Halal food trade deficit of the member states of the Organization of Islamic Cooperation (according to 2013 statistics, a sum of 7.8 billion dollars by 2025). However, Iran's share of Halal brand is now equal only to 0.25 percent of the world's while other Arabic and Islamic states of the region have gained a billion dollar profit in this market. Therefore, as a country whose entire food production is Halal, Iran has good potential and occasion in the domain of food production. In addition, Halal brand and the tendency of Islamic and non-Islamic countries to consume Halal food products, has provided Iran with a perfect opportunity to plan carefully and enter this international market faster.

Thus, this study seeks to answer the following questions:

1. What are the factors contributing to the early internationalization of new Halal food companies?

2. How should the factors contributing to the early internationalization of new Halal food companies be prioritized?

\subsection{Literature Review}

Exploring the ways in which ventures approach the issue of internationalization has been a major concern for international enterprise researchers since 1960`s and various theories have offered insights into the ways and the reasons why ventures pursue participation in international markets. According to Incremental theory (Uppsala-model) of internationalization developed by Johanson and Wiedersheim-Paul in 1977 (Kunday \& Senguler, 2015) the following factors determine the early internationalization of ventures; 1) the small psychological difference between the targeted market and the original market where the company operates, 2) knowledge and understanding of the market, and 3) the reduction of perceived risk due to the increase in empirical knowledge and understanding. Network theory suggests the network results in the early internationalization of ventures in the following ways; 1) Networks facilitate the access to the market knowledge, identifying key clients, financial resources and supporting R\&D activities. 2) Networks provide the founders of new ventures with new opportunities for enterprise and contribute to their entry into foreign markets. 3) Making use of networks to overcome the company`s limited chance to benefit from foreign markets. 4) Networks are valuable sources of market information, without which acquiring such knowledge would be costly and time-consuming. Ultimately, according to the theory of international entrepreneurship which, as Mtigwe (2006) points out, is located in the middle of the spectrum whose opposing extremes include the incremental theory of internationalization and the network theory, the role and characteristics of the entrepreneur plays a vital part in the early internationalization of ventures.

\subsubsection{The Early Internationalization of New Ventures and the Factors that Contribute to It}

According to Zhou \& Wu (2014), early internationalization is "a result of entrepreneurial spirit and entrepreneurial capability" and must be considered as an index of international entrepreneurial behavior (Teixeira \& Coimbra, 2014). It must be noted that concepts such as speed, pace, rapid, and accelerated are used by international enterprise researchers to explain the phenomenon of early and rapid internationalization. In general, the notion of speed refers to the amount or total of time required for an organization to achieve its goals (Casillas \& Acedo, 2013).

Examining the literature on early internationalization of ventures revealed that most of the studies focused on developing and testing the hypotheses concerning the role of speed and their principal purpose has been to find out the motive behind the rapid internationalization of ventures. One of the first issues introduced with regard to international entrepreneurship was the emphasis on Born Globals and international new ventures which undergo internationalization rapidly and in an early stage (Richard \& Saiyed, 2015). The notion of international new ventures is a combination of international enterprise and entrepreneurship (Matiusinaite \& Sekliuckiene, 2015). Rennie (1993) and Oviatt \& McDougall (1994) were the first to study international new ventures 20 years ago. With the increase in the number of the ventures which became international immediately after their emergence, the literature on this subject had de veloped as well (Richard \& Saiyed, 2015). Various scholars have used different definitions and terms to explore the international new ventures. For instance, the studies by Oviatt \& McDougall (1994) carried out throughout the world's six continents, covering both developed and developing economies, 
referred to such firms as "international new enterprises", "Born Globals", "the rapid internationals" and "international entrepreneurship". In his book, Hessels (2008) introduces "the rapid internationals" as an umbrella term encompassing various notions such as "instant exporter", "international new firm", "instant international", "Born Global" and "Born Global start-up".

Jones et al. (2011) believe that a Born Global is a kind of firm set up through a reliance on good network connections and the capability to compete internationally and coordinate the existing resources beyond borders. Gulko's (2013) definition of international new firms includes young enterprises targeting foreign markets immediately or a few years after their formation. In addition, Matiusinaite \& Sekliuckiene (2015) define international new ventures as small and medium-sized ventures that develop strategies in accordance with foreign markets right from the beginning and their income is mainly dependent on those markets. Further examination reveals that despite the fascination with international new ventures as unique organizations, few researchers have studied the course of their development (Jones, 2011).

Some writers such as Casillas et al. (2013), Jones et al. (2005) and Rialpet et al. (2005) believe that since the studies by Rennie (1993) and Oviatt (1994), the literature on factors contributing to early internationalization has become rather meager. The subject is of great contemporary significance and the studies on international enterprise has not explored it adequately (Richard \& Saiyed, 2015). In fact, there is no consensus with regard to the most important factors that determine the early internationalization of ventures (Matiusinaite \& Sekliuckiene, 2015). Having examined the relevant articles, we identified the factors offered in table 1.

Table 1 . the contributory factors to the early and rapid internationalization of new ventures

\begin{tabular}{|c|c|}
\hline factors & Authors \\
\hline Company Size & $\begin{array}{l}\text { Zahra,Ireland \& Hitt } \\
\qquad(2000)\end{array}$ \\
\hline nal orientation,Globalvision,previousexperience & Ibeh \& Yc \\
\hline technology resource,industry Competition & $\begin{array}{l}\text { Zahra,Mathern \& } \\
\text { Carleton (2003) }\end{array}$ \\
\hline $\begin{array}{l}\text { transportation technology,communication technology,social networks,tie } \\
\text { size,network density,foreign market knowledge }\end{array}$ & $\begin{array}{r}\text { Oviatt } \& \text { I } \\
(20\end{array}$ \\
\hline technology resource,Customer orientation & $\begin{array}{l}\text { Freeman, I } \\
\quad \text { Schrode }\end{array}$ \\
\hline Proactivity,tolerance for ambiguity,risk perception,manager mindset, international orientation & $\begin{array}{r}\text { Acedo } \\
(20\end{array}$ \\
\hline $\begin{array}{l}\text { business networks,social networks, foreign market knowledge,education abroad, international } \\
\text { orientation, previous experience,international experience, born abroad,foreign language } \\
\text { social networks,the level of institutional development ofcountry }\end{array}$ & $\begin{array}{l}\text { Zucchella, P } \\
\text { \& Denicolai } \\
\text { Kiss \& Dan }\end{array}$ \\
\hline $\begin{array}{l}\text { business networks, social networks,human capital, financial resource, } \\
\text { resource,recognition and exploitation of international market opportunities }\end{array}$ & $\begin{array}{l}\text { Chandra,Styles \& } \\
\text { Wilkinson (2009) }\end{array}$ \\
\hline $\begin{array}{l}\text { social networks, buying-in knowledge,exploit technology motivation, risk } \\
\text { Entrepreneurial Orientation,previous experience, planning }\end{array}$ & Crick (2009) \\
\hline investment & Chang (2011) \\
\hline $\begin{array}{l}\text { foreign market knowledge, human capital, financial resource, technology resource, industry } \\
\text { Competition, recognition and exploitation of international market opportunities,company's } \\
\text { competitive advantage, government regulation }\end{array}$ & Kotosaka (2011) \\
\hline human capital, financial resource, resource technolog ,previous experience & $\begin{array}{l}\text { De Clercq, } \\
\text { Yavuz \& Zh }\end{array}$ \\
\hline business networks, social networks, foreign market knowledge, international experience & $\begin{array}{c}\text { Kalinic \& Forza } \\
(2012)\end{array}$ \\
\hline & Gulko (2013) \\
\hline $\begin{array}{l}\text { financial resource, industry Competition, Education abroad, global } \\
\text { company age, International alliances and Joint ventures }\end{array}$ & $\begin{array}{l}\text { Casillas \& Acedo } \\
\qquad \text { ( 2013) }\end{array}$ \\
\hline $\begin{array}{l}\text { institutional bridging and capacity for cross-cultural collaboration, risk perception, networking } \\
\text { capabilities }\end{array}$ & $\begin{array}{c}\text { Rezvani \& } \\
\text { Musavinejad (2014) }\end{array}$ \\
\hline
\end{tabular}
In general, these factors fall into 8 main categories including "technology", "network", "company resources", "country features", "industry features", "company features", "managerial characteristics" and "knowledge".

Therefore research framework would present like this: 


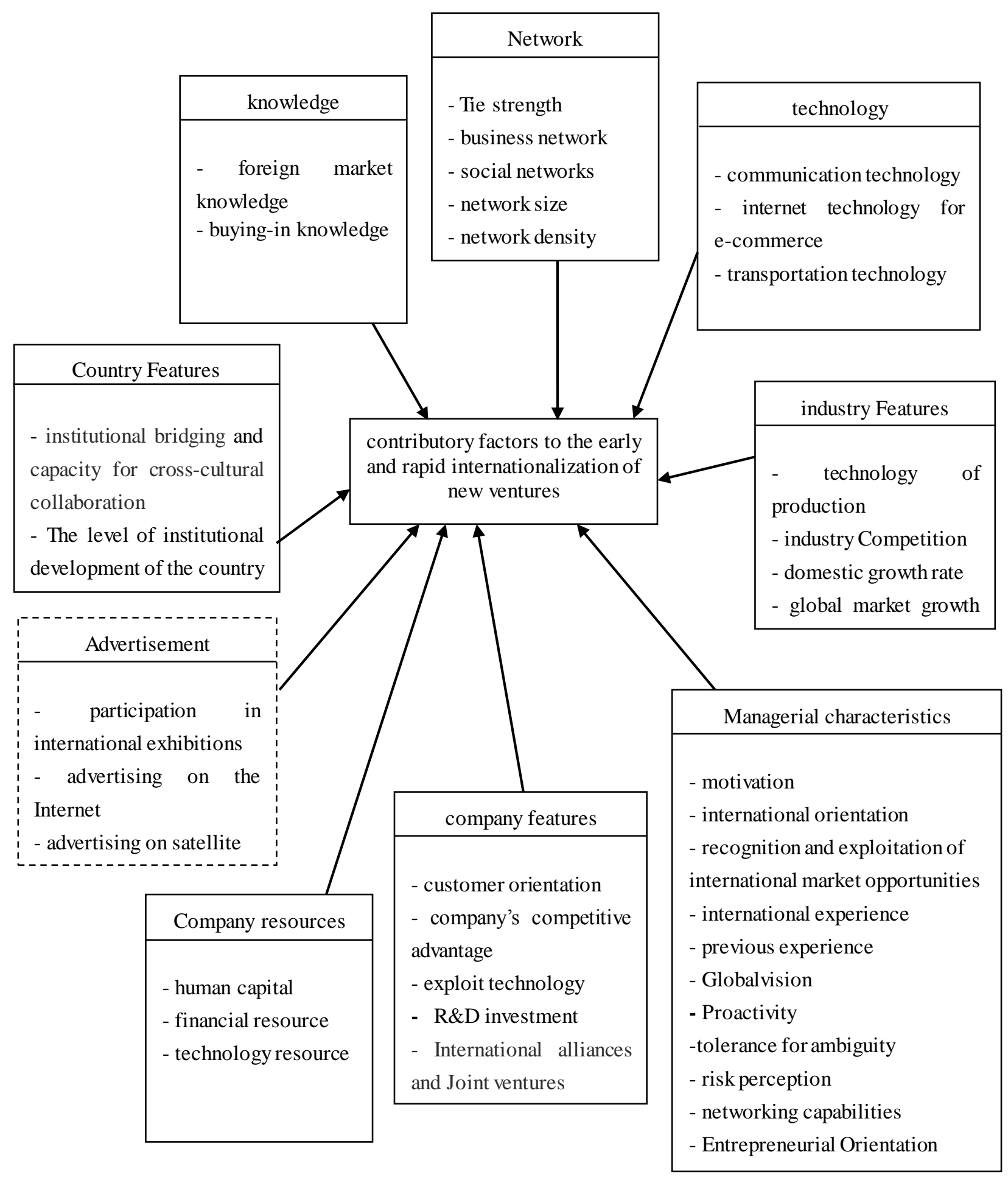

Figure 1. Research framework according to systematic review of literature 


\section{Methodology}

Methodologically, this is a quantitative survey study, a practical research relying on data collection based on the objective. Following the survey method, questionnaires are employed for collecting data.

The statistical population consists of chief officers (CEO, CMO, CPO, CSO, etc.) and the experts working in each of the aforementioned fields in international new Halal food companies in Iran. Therefore, first, a list of companies holding Halal certification - including 1000 firms, active in various industries - has been collected from the Halal Institute database. Examining the final list revealed that only $12 \%$ (100 companies) of the total 800 firms operating in food industry have seized the opportunity for turning into an international new venture. Therefore, the statistical population of the study consists of chief officers and the experts spread across these 100 Halal food international new ventures and the sample size is equal to 80 based on the Cochran formula.

In order to examine the theoretical background and the existing literature on the subject, this study has employed secondary research methods And also, we have done our best to consider all of the authors from 1996 to 2016 and have made sure that their theories about early internationalization are collected. This step has two advantages: 1- Reaching a comprehensive list of contributing factors of early and quick internationalization and when these factors are noticed and considered, the possibility of finding more contributing factors that are not already presented in the collected list is very low. 2- Having studied the identified contributing factors, we can find out which contributing factor has been emphasized the most amongst authors. After finishing the theoretical framework, validating the list of contributing factors is necessary so having determined the theoretical framework, we de vised a questionnaire including 46 questions in three areas: 1) demography, 2) main questions, and 3) open questions. The two later categories used Likert scale ranging from 5 representing very much to 1 representing very little.

Table 2. the Cronbachs alpha coefficients, the construct Composite reliability of the study

\begin{tabular}{ccccc}
\hline factors & Number of questions & AVE & Cronbachs Alpha & Composite Reliability \\
\hline technology & 3 & 0.749 & 0.882 & 0.897 \\
network & 5 & 0.787 & 0.944 & 0.948 \\
company features & 7 & 0.711 & 0.932 & 0.945 \\
Company resources & 3 & 0.923 & 0.958 & 0.973 \\
country features & 3 & 0.882 & 0.933 & 0.957 \\
Industry Features & 4 & 0.885 & 0.956 & 0.968 \\
managerial characteristics & 16 & 0.574 & 0.948 & 0.954 \\
knowledge & 2 & 0.931 & 0.931 & 0.964 \\
advertisement & 3 & 0.915 & 0.961 & 0.969 \\
\hline
\end{tabular}

The devised questionnaire was examined by some scholars for the purpose of evaluating content validity. Consequently, "advertisement" was added to the list of factors contributing to early internationalization of Halal food international new ventures. Next, the convergent validity of the questionnaire was examined by PLS software which, as it is indicated in table 2, revealed that AVE for all factors is higher than the 0.5 critical value. For an evaluation of the reliability of the questionnaire, the study has made use of Cronbach's alpha and combinatorial reliability. Once these methods ensured reliability, the questionnaires were distributed among the statistical population. Since the Alpha coefficients for each contributing factors is higher than 0.7, so the questionnaire has enough reliability.

SPSS was used to analyze the data. First, the descriptive statistics including mean (a measure of central tendency) and the three standard de viations (index of dispersion), variance and variation range were measure d. Afterwards, inferential statistics were considered; for instance, one-sample $\mathrm{T}$ was used to test the significance and the utility of variables and the one-sample $\mathrm{T}$ test is used for the average perimeter assumption test for a society. In majority of the studies that are done using the Likert scale, in order to study and analyze the questions based on the article, this test is used and finally Friedman test made it possible to rank and prioritize variables and research index.

\section{Findings}

The analysis of the questionnaire showed that sales experts comprised 20 percent of the participants, 42.5 percent had 11 to 15 years work experience, and 28.8 percent worked in "production and packaging of red meat products".

As table 3 shows, the highest means belongs to "manager traits" and "company features", respectively, while "knowledge" and "advertisement" make for the lowest mean. 
Table 3. Descriptive statistics of factors contributing to the early internationalization of new ventures

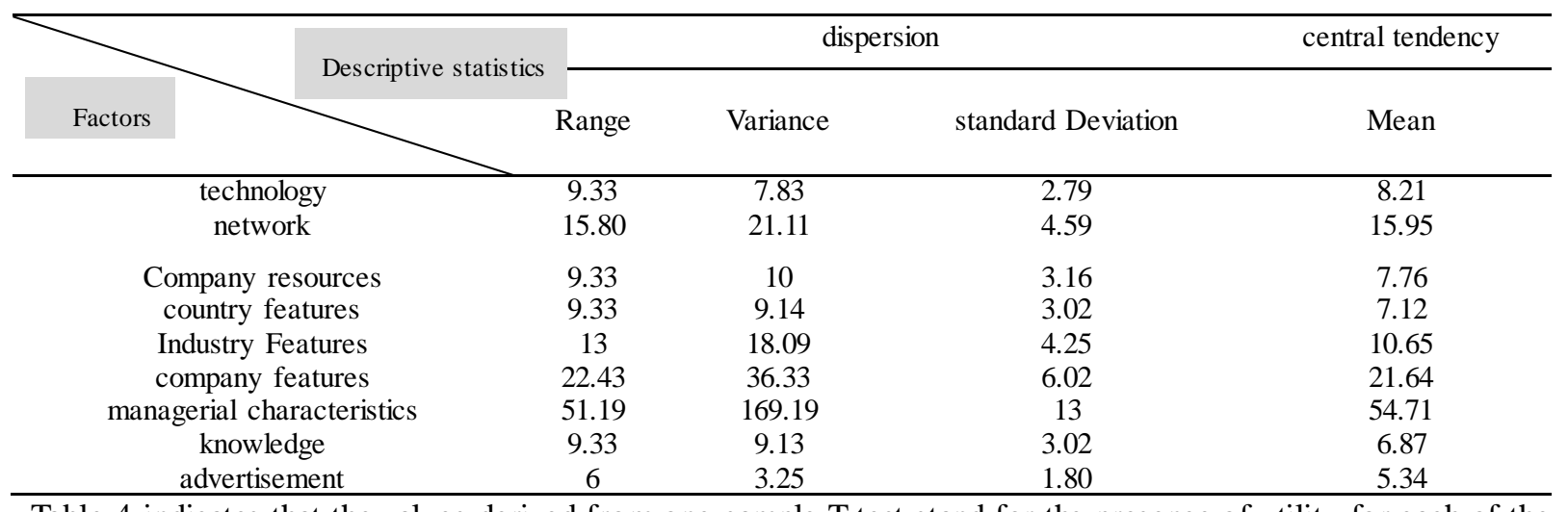

Table 4 indicates that the values derived from one-sample T test stand for the presence of utility for each of the factors that determine the early internationalization of Halal food international new ventures.

Table 4. One-sample $\mathrm{T}$ test for the contributing factors to the early internationalization of Halal food international new ventures

\begin{tabular}{|c|c|c|c|c|c|c|c|}
\hline \multirow{3}{*}{ factors } & \multicolumn{7}{|c|}{ Test Value $=3$} \\
\hline & \multirow[t]{2}{*}{$\mathrm{t}$} & \multirow[t]{2}{*}{$\begin{array}{l}\text { Degree of } \\
\text { freedom }\end{array}$} & \multirow[t]{2}{*}{$\begin{array}{c}\text { significance } \\
\text { level }\end{array}$} & \multirow[t]{2}{*}{$\begin{array}{c}\mathrm{d} \\
\text { (Error) }\end{array}$} & \multirow[t]{2}{*}{$\begin{array}{c}\text { Mean } \\
\text { Difference }\end{array}$} & \multicolumn{2}{|c|}{$\begin{array}{l}95 \% \text { Confidence } \\
\text { Interval of the } \\
\text { Difference }\end{array}$} \\
\hline & & & & & & Lower & Upper \\
\hline technology & 16.65 & 79 & 0.00 & 0.05 & 5.21 & 4.58 & 5.83 \\
\hline network & 25.20 & 79 & 0.00 & 0.05 & 13.97 & 11.92 & 13.97 \\
\hline Company resources & 13.46 & 79 & 0.00 & 0.05 & 5.46 & 4.05 & 5.46 \\
\hline country features & 12.18 & 79 & 0.00 & 0.05 & 4.79 & 3.44 & 4.79 \\
\hline Industry Features & 16.09 & 79 & 0.00 & 0.05 & 8.60 & 6.70 & 8.60 \\
\hline company features & 27.66 & 79 & 0.00 & 0.05 & 19.98 & 17.30 & 19.98 \\
\hline managerial characteristics & 35.55 & 79 & 0.00 & 0.05 & 54.60 & 48.81 & 54.60 \\
\hline knowledge & 11.45 & 79 & 0.00 & 0.05 & 4.54 & 3.19 & 4.54 \\
\hline advertisement & 11.61 & 79 & 0.00 & 0.05 & 2.74 & 1.94 & 2.74 \\
\hline
\end{tabular}

According to table 5 which examines the degree of importance for factors in the early internationalization of Halal food international new ventures, "managerial characteristics" and "company features" are the top priorities while "knowledge" and "advertisement", respectively, have the least contribution to the early internationalization of Halal food international new ventures.

Table 5. Ranking contributing factors to the early internationalization of Halal food international new ventures

\begin{tabular}{ccc}
\hline Ranks & Mean Rank & $\begin{array}{c}\text { contributing factors to the early internationalization of international new ventures in } \\
\text { Halal food industry }\end{array}$ \\
\hline 1 & 8.95 & managerial characteristics \\
company features \\
2 & 7.55 & network \\
3 & 6.63 & industry features \\
4 & 4.99 & technology \\
5 & 4.04 & company resources \\
6 & 3.83 & country features \\
7 & 3.39 & advertisement \\
8 & 3.20 & knowledge \\
9 & 2.43 & \\
\hline
\end{tabular}

\section{Conclusion}

The study set out to introduce the contributing factors to the early internationalization of international new ventures working in Iranian Halal food industry and also prioritize the identified factors. Foreign studies have approached the identification of these factors form various perspectives, but this study has not limited its focus on a specific factor or a series of similar ones; rather, it offers a comprehensive framework for the contributing factors to the early internationalization of international new ventures as well as prioritizing the factors based on their importance for the early internationalization of Halal food international new ventures in Iran. This could be considered the original contribution of this study. To ans wer the two questions posed in the beginning of the study, a series of contributing factors to the early internationalization of new ventures were identified through an exploration of the theoretical context and after integrating the scholars' outlook another factor was added to the list of the identified factors, viz. advertisement. In order to see whether they contribute to the early 
internationalization of Halal food international new ventures in Iran or not, and evaluate the possible outcome, data were collected through questionnaires. Table 6 contains the results derived from data analysis.

Table 6. Ranking the indicators and factors that determine the early nationalization of Halal food international new ventures

\begin{tabular}{|c|c|c|c|}
\hline $\begin{array}{c}\text { contributing indicators to the early } \\
\text { internationalization of international new ventures } \\
\text { in Halal food industry }\end{array}$ & $\begin{array}{l}\text { Ranking } \\
\text { indicators }\end{array}$ & $\begin{array}{c}\text { contributing factors to the early } \\
\text { internationalization of international } \\
\text { new ventures in Halal food } \\
\text { industry }\end{array}$ & $\begin{array}{l}\text { Ranking } \\
\text { Factors }\end{array}$ \\
\hline motivation & 1 & & \\
\hline international orientation & 2 & & \\
\hline $\begin{array}{l}\text { recognition and exploitation of international } \\
\text { market opportunities }\end{array}$ & 3 & managerial characteristics & 1 \\
\hline Customer orientation & 1 & & \\
\hline company's competitive advantage & 2 & company features & 2 \\
\hline exploit technology & 3 & & \\
\hline Tie strength & 1 & & \\
\hline business network & 2 & network & 3 \\
\hline social networks & 3 & & \\
\hline technology of production & 1 & & \\
\hline industry Competition & 2 & & \\
\hline domestic growth rate & 3 & industry Features & 4 \\
\hline global market growth rat & 4 & & \\
\hline communication technology & 1 & & \\
\hline internet technology for e-commerce & 2 & technology & 5 \\
\hline transportation technology & 3 & & \\
\hline human capital & 1 & & \\
\hline financial resource & 2 & Company resources & 6 \\
\hline technology resource & 3 & & \\
\hline $\begin{array}{c}\text { institutional bridging and capacity for } \\
\text { cross-cultural collaboration }\end{array}$ & 1 & & \\
\hline $\begin{array}{l}\text { The level of institutional development of the } \\
\text { country }\end{array}$ & 2 & Country Features & 7 \\
\hline government regulation & 3 & & \\
\hline participation in international exhibitions & 1 & & \\
\hline advertising on the Internet & 2 & advertisement & 8 \\
\hline advertising on satellite & 3 & & \\
\hline foreign market knowledge & 1 & & \\
\hline buying-in knowledge & 2 & knowledge & 9 \\
\hline
\end{tabular}

According to the findings of this study, "managerial characteristics" has been the most important factor in the early nationalization of Iranian Halal food international new ventures. In this regard, we can refer to studies by some researchers such as Matiusinaite \& Sekliuckiene (2015) and Danik et al. (2016) which consider an integral part for management in the early internationalization of new ventures. Friedman et al. (2006) emphasizes the significance of "company features" and suggests that the tendency of new ventures towards customer orientation wins them new foreign customers, which increases their reputation across foreign networks. Consequently, the company will receive more customers, a fact that reflects the rapid development of its international activities. Moreover, in order to achieve a stable export, the examined ventures have counted on customers as permanent allies and considered the understanding of customer, personalization and the adaptation of services and products with customer demands as the prime condition of a product's repute. The study's findings concerning "network" indicates that, as Tang (2011) has pointed out, the greater the power (knowledge, financial resources, etc.) of people and enterprises in the network, the more information is granted them about new business opportunities, potential markets, etc. and the more possibilities for them to make use of such information. As a result, new ventures can become internationalized in an early stage. Regarding the significance of "indus try features", it can be said that Iranian food industry is in a better shape than the country's other industries which have often lagged behind world technology. As Matiusinaite \& Sekliuckiene (2015) have noted in their study, the process of the internationalization of new international ventures is much influenced by the industry and technological aspects of the original industry of the ventures. Findings with regard to the role of technology confirms the studies by Knight \& Cavusgil in 1996 and those by Oviatt \& McDougall in 1999, which revealed that the technological developments in transportation, communication and computer allow the new ventures to become internationalized more rapidly (Oviatt \& McDougall 2005). The results concerning the significance of "company resources" and particularly "human capital" reinforce suggestions offered by De clercq et al. (2012) as well as those presented by Rezvani and Musavinejad (2014) according to which, compared to some features of the 
company such as its size and age, the social resources(human capital) of the management team is more important in its internationalization. Considering the fact that the examined ventures usually export to the neighboring countries which resemble them more in terms of institutional distance, the findings about the significance of "country features" (institutional bridging and capacity for cross-cultural collaboration) are in line with position taken by Casillas \& Acedo (2013). The literature shows that in his study, Evers (2010) refers to "trade fairs" as one of the factors that contribute to the early internationalization of ventures, which confirms the findings of this study. The importance of "access to knowledge about the international market" in the early internationalization of the examined ventures confirms the findings of kutosaka)2011(, Kalinic \& Forza (2012) about this factor. Furthermore, regarding the open question posed in the questionnaire, "Halal brand" has proved to be one of the contributing factors to the early internationalization of Halal food international new ventures in Iran.

And to conclude, if international new ventures in halal food industry consider the contributing factors in this study in the same order and have a plan based on these factors, these companies can undoubtedly succeed in the highly competitive circumstances of foreign markets and according to the halal food approach, Iran will be able to reach first place for halal food trading, find a place amongst the top 5 countries who are members of the Organization of Islamic Cooperation and reaching $10 \%$ of the annual exports in halal food trading in Organization of Islamic Cooperation countries.

\section{Suggestions}

This study has provided managers and policy makers with several discoveries including the fact that policy makers must concentrate on a series of secondary programs that accelerates international learning. Such programs will subsequently facilitate international commitment and function. An instance includes holding seminars where managers share their international experiences and learn from one another, rather than waiting for a personal experience to equip them with such knowledge. The following are the practical suggestions of this study: 1) the increasing presence of international new ventures in international exhibitions to introduce themselves to customers and expand their enterprise networks, 2) Zahra et al. (2003) believes that the internationalization of ventures is expensive; therefore, the prioritization of the identified factors allow the managers to focus on factors with higher priorities so that they can internationalize their ventures at a lower cost.

Based on the exploration of theoretical context and the findings of previous literature as well as the results of this study, the following suggestions regarding further research are offered: 1) a careful examination of the role of Halal brand in the early internationalization of Halal food international new ventures, 2) the identification of factors which hinder the early internationalization of new ventures, and 3) carrying out this study through mixed method. Thus, new findings can be achieved in this field through interviews with scholars, and data coding and analysis by relevant software.

\section{References}

Acedo, F. J., \& Jones, M. V. (2007). Speed of Internationalization and Entrepreneurial Cognition: Insights and a Comparison Between International New Ventures, Exporters and Domestic Firms. Journal of World Business, 42, 236-252. https://doi.org/10.1016/j.jwb.2007.04.012

Casillas, J. C., \& Acedo, F. J. (2013). Speed in the Internationalization Process of the Firm. International Journal of Management Reviews, 15, 15-29. https://doi.org/10.1111/j.1468-2370.2012.00331.x

Chandra, Y., Styles, C., \& Wilkinson, I. (2009). The Recognition of First Time International Entrepreneurial Opportunities: Evidence from firms in Knowledge-based industries. International Marketing Review, 26(1), 30-61. https://doi.org/10.1108/02651330910933195

Chang, J. (2011). The Early and Rapid Internationalization of Asian Emerging MNEs. Competitiveness Review: An International Business Journal, 21(2), 171-187. https://doi.org/10.1108/10595421111117452

Crick, D. (2009). The Internationalisation of Born Global and International New Venture SMEs. International Marketing Review, 26(4/5), 453-476. https://doi.org/10.1108/02651330910971986

Danik, L., Duliniec, E., \& Kowalik, I. (2016). The Polish Born Global Firms: Founding Processes and Motives of Early Internationalization. Transformation in Business \& Economics, 15(2), 111-130.

De Clercq, D., Hessels, J., \& Van Stel, A. J. (2008). Knowledge Spillovers and New Ventures' Export Orientation. Small Business Economics, 31(3). https://doi.org/10.1007/s11187-008-9132-z

De Clercq, D., Sapienza, H. J., Yavuz, R. I., \& Zhou, L. (2012). Learning and Knowledge in Early Internationalization Research: Past Accomplishments and Future Directions. Journal of Business Venturing, 27, 143-165. https://doi.org/10.1016/j.jbusvent.2011.09.003 
Etemad, H., \& Wright, R. (2003). Globalization and Entrepreneurship: Policy and Strategy Perspective, 3-14, Cheltenham \& Massachusetts,Edward Elgar Publishing.

Freeman, S. A., Edwards, R., \& Schroder, B. (2006). How Smaller Born-Global Firms Use Networks and Alliances to Overcome Constraints to Rapid Internationalization. Journal of International Marketin, American Marketing Association, 14(3), 33-63. https://doi.org/10.1509/jimk.14.3.33

Gulko, O. (2013). Importance of networks for International New Ventures entry to Russian and Ukrainian steel industry market. Master Thesis, Faculty of Econimics and Business Administration.

Hessels, J. (2008). International Entrepreneurship: Value creation across national borders, 9-29. Rotterdam, Erasmus Research Institute of Management (ERIM).

Hohenthal, J., Johanson, J., \& Johanson, M. (2003). Market Discovery and the International Expansion of the Firm. International Business Review, 12, 659-672. https://doi.org/10.1016/j.ibusrev.2003.06.001

Ibeh, K. I. N., \& Young, S. (2001). Exporting as an Entrepreneurial Act - An Empirical Study of Nigerian Firms. European Journal of Marketing, 35(5/6), 566-586. https://doi.org/10.1108/03090560110388114

Johnson, H., \& Sandberg, S. (2008).Internationalization of Small and Medium Sized Enterprises in the Baltic Sea Region. Journal of international management, 14, 65-77. https://doi.org/10.1016/j.intman.2007.02.005

Jones, M. V., Caviello, N., \& Tang, Y. K. (2011). International Entrepreneurship Research (1989-2009): a domain ontology and thematic analysis. Journal of Business Venturing. https://doi.org/10.1016/j.jbusvent.2011.04.001

Kalinic, I., \& Forza, C. (2012). Rapid Internationalization of Traditional SMEs: Between Gradualist Models and Born Globals. International Business Review, 21, 694-707. https://doi.org/10.1016/j.ibusrev.2011.08.002

Kiss, A. N., \& Danis, W. M. (2008). Country Institutional Context, Social Networks and New Venture Internationalization Speed. European Management Journal, 26, 388-399. https://doi.org/10.1016/j.emj.2008.09.001

Kotosaka, M. (2011). Modelling the Speed: Examining the Different Modes of Internationalization by the Timing and Speed, SSRN. Available at SSRN: https://ssrn.com/abstract=1969313 or http://dx.doi.org/10.2139/ssrn.1969313.

Kunday, O., \& Sengüler, E. P. (2015). A Study On Factors Affecting The Internationalization Process Of Small And Medium Enterprises (SMEs). Social and Behavioral Sciences, 195, 972-981. https://doi.org/10.1016/j.sbspro.2015.06.363

Matiusinaite, A., \& Sekliuckiene, J. (2015). Factors Determining Early Internationalization of Entrepreneurial SMEs. Theoretical Approach. Entrepreneurship, 175-185.

Mtigwe, B. (2006). Theoretical Milestones in International Business: The Journey to International $\begin{array}{lllll}\text { Entrepreneurship Theory. } & \text { International }\end{array}$ https://doi.org/10.1007/s 10843-006-5872-5

Oviatt, B. M., \& McDougall, P. P. (1994). Toward a Theory of International New Ventures. Journal of International Business Studies, 36, 29-41. https://doi.org/10.1057/palgrave.jibs.8490193

Oviatt, B. M., \& McDougall, P. P. (2005). Defining International Entrepreneurship and Modeling the Speed of $\begin{array}{lllll}\text { Internationalization. } & \text { Entrepreneurship Theory } \& \text { Practice, }\end{array}$ https://doi.org/10.1111/j.1540-6520.2005.00097.x

Rezvani, M., \& Hajifathali, A. (2013). The Effect of Organizational Factors on Business Growth in International Franchises; The Case of Iranian Food Industry. Asian Journal of Research in Business Economics and Management, 3(9), 45-58.

Rezvani, M., \& Musavinejad, S. M. (2014). International Entrepreneurship. Iran: University of Tehran Press.

Ricard, A., \& Saiyed, A. A. (2015). Attitude Toward Internationalization And Early Internationalization: Comparison of Indian and French SMEs' Decision Makers. Management, 18(1), 54-77.

Teixeira, A. A., \& Coimbra, C. (2014). The Determinants of the Internationalization Speed of Portuguese University Spin-offs. An Empirical Investigation. Journal of International Entrepreneurship, 12, 270-308. https://doi.org/10.1007/s 10843-014-0132-6

Yang, H. J., Dube, F., \& Huang, L. J. (2016). Research on the Factors Influencing Halal Food Industry Internationalization: A Case Study of Ningxia (China). 3rd International Conference on Economics and 
Management. https://doi.org/10.12783/dtem/icem2016/4069

Zahra, S. A., Ireland, R. D., \& Hitt, M. A. (2000). International Expansion by New Venture Firms: International Diversity, Mode of Market Entry, Technological Learning and Performance. Academy of Management Journal, 4(5), 925-950. https://doi.org/10.2307/1556420

Zahra, S. A., Mathern, B. P., \& Carleton, J. M. (2003). Technological Resource Leveraging and the International of New Ventures. Journal of International Entrepreneurship, 1, 163-186. https://doi.org/10.1023/A:1023852201406

Zucchella, A., Palamara, G., \& Denicolai, S. (2007). The Drivers of the Early Internationalization of the Firm. Journal of World Business, 42, 268-280. https://doi.org/10.1016/j.jwb.2007.04.008

\section{Copyrights}

Copyright for this article is retained by the author(s), with first publication rights granted to the journal.

This is an open-access article distributed under the terms and conditions of the Creative Commons Attribution license (http://creativecommons.org/licenses/by/4.0/). 